\title{
Influence of Physical and Chemical Treatments upon the Microsomal Enzymes of Testes related to Androgen Biosynthesis*
}

\author{
AYAKo MACHINO**, HIDEKI NAKANO AND BUN-ICHI TAMAOKI \\ National Institute of Radiological Sciences, \\ Anagawa-4-chome, Chiba-shi 280
}

\begin{abstract}
Synopsis
Testicular microsomal fraction $(10,000 \sim 105,000 \mathrm{x}$ g precipitates $)$ of adult rats which was responsible for enzymic transformation of pregnenolone into testosterone was inactivated by phospholipases $C$ and $D$, but not by phospholipase A. After the 10 kilocycles/sec. sonication for 60 mins., most of the microsomal enzyme activities were still found in the $105,000 \mathrm{x}$ g precipitates. The specific activities of the enzymes in the precipitates at $105,000 \times \mathrm{g}$ became higher than those of the untreated microsomal particles, as inactive protein was solubilized from the microsomal fraction by this sonication. After the 20 kilocycles/sec. sonication for 5 mins., however, appreciable activities of the testicular enzymes related to testosterone formation were found in the supernatant fluid at $105,000 \mathrm{xg}$, but were mostly precipitated at $165,000 \mathrm{xg}$ for $5 \mathrm{hrs}$., indicating that the sonication modified the microsomal structure of testis without serious loss of the enzyme activities related to the androgen biosynthesis. Influences of the phospholipases $\mathrm{A}$ and $\mathrm{C}$ upon the 20 kilocycles/sec. sonicated microsomal fraction of testes were similar to those of the same enzymes upon the intact microsomes. By treatments of it with organic solvents, surface active reagents, and freezing and thawing procedure, the microsomal enzymes could not be solubilized with retention of the enzyme activities.

From the results obtained by the above physical and chemical treatments against testicular microsomal fraction, the status of the testicular enzymes in the microsomal structure was discussed.
\end{abstract}

Received for publication November 13, 1968. * Dedicated to Professor Yosoji ITO in commemoration of his unselfish devotion for over fifteen years to the advancement of endocrinological science through the editorial management of Endocrinologia Japonica.

** Visiting scientist from the Research Laboratory, Chugai Pharm. Co. Ltd., Tokyo.

*** The following trivial names were used in this text. pregnenolone, $3 \beta$-hydroxypregn-5-en-20-one; progesterone, pregn-4-ene-3,20-dione; 17a-hydroxyprogesterone, 17a-hydroxypregn-4-ene-3,20-dione; androstenedione, androst-4-ene-3, 17-dione; testosterone, 17 $\beta$-hydroxyandrost-4-en-3-one; NAD, nicotinamide adenine dinucleotide; and NADPH, reduced form of nicotinamide adenine dinucleotide phosphate.
The testicular enzyme system which concerned with production of testosterone*** from pregnenolone was concentrated exclusively to the testicular microsomal fraction $(10,000 \sim 105,000 \times \mathrm{g}$ precipitates $)$ of the interstitial cells, while the soluble fraction of testicular glands $(105,000 \times \mathrm{g}$ supernatant fluid) contained the $20 \alpha$-hydroxysteroid dehydrogenase and the activating principle upon the above mentioned enzyme activities of the microsomes (Shikita and Tamaoki, 1965; Inano and Tamaoki, 1968; Shikita et al., 1967).

On the other hand, enzyme activities associated with the membrane system of liver 
and other organs were biochemically studied, and among them, a limited number of enzymes were reported to be solubilized by physical and chemical treatments (Reid, 1967). As to the enzymes related to the steroidogenesis, one constituent of the 21-hydroxylase system which was associated with adrenal microsomes was isolated and purified as cytochrome P-450, which plays the role of activating the molecular oxygen in the course of the hydroxylation (Omura et al., 1965).

In this paper, the enzymes related to testosterone biosynthesis from pregnenolone were studied of the status in the microsomes, by application of several physical and chemical treatments which had been used for solubilization of microsomal enzymes.

\section{Materials and Methods}

\section{Radioactive steroid precursors}

Progesterone-4- ${ }^{14} \mathrm{C} \quad(146.6 \quad \mu \mathrm{C} i / \mathrm{mg})$, androstenedione- $4{ }^{14} \mathrm{C} \quad(71.0 \quad \mu \mathrm{Ci} / \mathrm{mg})$ and $17 \alpha$-hydroxyprogesterone- $7 \alpha-{ }^{-3} \mathrm{H}(0.025 \mu \mathrm{Ci} / \mathrm{mg})$ were purchased from New England Nuclear Corp. (Boston, Mass., U.S.A.), and pregnenolone- $4-{ }^{14} \mathrm{C} \quad(738.3 \mu \mathrm{Ci} / \mathrm{mg})$ and $\quad 17 \alpha$-hydroxyprogesterone-4- ${ }^{14} \mathrm{C} \quad(113.6$ $\mu \mathrm{C} i / \mathrm{mg}$ ) were obtained from Radiochemical Centre (Amersham, England). These radioactive steroids were diluted respectively with non-radioactive steroids, and appropriate amounts of substrates were added to the testicular enzyme preparations, so that saturation of the substrates with the used enzyme preparations was insured. Before use, the radiochemical purities of the radioactive steroids were examined by thin layer chromatography.

\section{Phospholipases}

The following phospholipase preparations were used in this experiment to modify the phospholipids of the testicular microsomes.

Phospholipase A (Phosphatide acyl-hydrolase): This preparation was prepared from the venom of Russell vipers and was free from the proteolytic enzymes. Shortly before use, the activity was assayed by the method of Habermann and Neumann (1954).

Phospholipase C (Phosphatidylcholine cholinephosphohydrase): The enzyme preparations used were prepared by the fractional precipitation with ammonium sulfate from the filtrate of the media in which the following bacteria were cultured (Macfarlane and Knight, 1941; Molnar, 1962). In this paper, the phospholipase which originated in Bacillus cereus was denoted as $C_{1}$ and the one obtained from Clostridium welchii was designated as $\mathrm{C}_{2}$. Phospholipase D (Phosphatidylcholine phosphatidohydrolase): The preparation was extracted and purified from the cabbage leaves (Matsumoto, et al., 1967).

\section{Tissue preparation}

Male rats of the Wistar strain (about 2 monthold), bred in this Institute were used for this experiment. Immediately after decapitation of the animals, the testicular glands were removed and reserved in the chilled $0.25 M$ sucrose solution. The glands were decapsulated and then homogenized in twice their weight of ice-cold $0.25 \mathrm{M}$ sucrose solution with a loose-fitting Teflon-glass homogenizer. The homogenates were then centrifuged at $800 \times \mathrm{g}$ for $20 \mathrm{mins}$.

The precipitates containing unbroken cells, cell wall, nuclei, and other large particles, etc. were discarded. The supernatant fluid obtained at 10,000 $\times \mathrm{g}$ was centrifuged at $10,000 \times \mathrm{g}$ once more for 20 mins. to remove the mitochondrial contaminants, and then, the supernatant fluid was centrifuged at $105,000 \times \mathrm{g}$ for $60 \mathrm{mins}$. The precipitates were suspended in 50 times their weight of $0.25 \mathrm{M}$ sucrose solution, sedimented again at $105,000 \times \mathrm{g}$, and was used as the microsomal fraction. According to electron microscopic examination, the microsomal fraction thus obtained was found as the mixture of rough and smooth-surfaced microsomes, but not contaminated with its mitochondrion (Inano and Tamaoki, unpublished findings).

\section{Incubation}

The radioactive precursors were transfered to the incubation flasks to which two drops of propylene glycol per each flask and NADPH or NAD as cofactor were then added. Thereafter, testicular microsomal preparations which had been treated by several physical and chemical procedures were added to the flask mentioned above. Each mixture was incubated at $37.5^{\circ}$ for 60 mins. with continuous shaking, under the atmosphere of the $\mathrm{O}_{2}-\mathrm{CO}_{2}(95: 5)$ mixture.

\section{Extraction and isolation of the metabolic prod- ucts}

Immediately after the incubation of the steroid substrates with the testicular microsomal preparation, $15 \mathrm{ml}$ of methylene dichloride was added to each incubation flask, and the mixture was shaken vigorously to arrest any further enzyme reaction. After centrifugation of it at $400 \times \mathrm{g}$ for 10 mins., the 
lower layer was removed by a pipette and reserved. The upper layer which contained denatured protein precipitate was reextracted twice more with $15 \mathrm{ml}$ of methylene dichloride, each time. The pooled extract was dehydrated with anhydrous sodium sulfate and evaporated to dryness under the reduced pressure at room temperature. Then, thus obtained steroid fraction was subjected to the analysis of silica-gel thin layer chromatography for separation of the metabolites, developed by the benzene-acetone $(18: 2)$ system, and other systems, as previously reported (Shikita and Tamaoki, 1965).

\section{Quantitation of the sterioid metabolites}

The steroid fractions were separated and purified by repeated thin-layer chromatographies with and without chemical derivations, after extraction from the scraped silica-gel powder on the spots which were detected autoradiographically. An aliquot of the extract was transfered to a counting vial, and the organic solvents were evaporated with a stream of nitrogen. Then, $11 \mathrm{ml}$ of the liquid scintillator which consisted of PPO or 2,5-diphenyloxazole $0.4 \%$ and POPOP or 1,4-di-[2-(5-phenyloxazolyl)]-benzene $0.01 \%$ in the redistilled toluene was added to the vial, and then, the radioactivity of the ${ }^{14} \mathrm{C}$ or ${ }^{3} \mathrm{H}$ involved in the sample was measured by a liquid scintillation spectrometer (Nuclear Chicago, System 725, Des Plaines, Ill., U.S.A.). The efficiency of counting radiocarbon was $74 \%$, and, for the double isotope tracer experiment, the efficiencies of simultaneous counting ${ }^{14} \mathrm{C}$ and ${ }^{3} \mathrm{H}$ were respectively $57 \%$ and $32 \%$.

\section{Expression of the enzyme activities related to androgen biosynthesis}

As all the enzymes related to testosterone formation from pregnenolone or, $\Delta^{5}-3 \beta$-hydroxysteroid dehydrogenase with $\Delta^{5}-\Delta^{4}$ isomerase, $17 \alpha$-hydroxylase, $\mathrm{C}_{17}-\mathrm{C}_{20}$ lyase and $17 \beta$-hydroxysteroid dehydrogenase were located together in the testicular microsomal fraction and could not be separated from each other at the present, the testicular enzyme activities were expressed tentatively as follows; $\Delta^{5}-3 \beta$-hydroxysteroid dehydrogenase together with the isomerase was expressed as the sum of $\Delta^{4}-3$ oxosteroids and their derivatives originating in the pregnenolone added as the substrate. $17 \alpha$ Hydroxylase activity was expressed as the sum of $17 \alpha$-hydroxy progesterone, androstenedione, testosterone and their derivatives, transformed from the progesterone which was used as the substrate. The $\mathrm{C}_{17}-\mathrm{C}_{20}$ lyase activity was designated as the sum of androstenedione, testosterone and other C-19 steroids derived by the side-chain cleavage of
$17 \alpha$-hydroxyprogesterone. $\quad 17 \beta$-Hydroxysteroid dehydrogenase activity was expressed as the yield of the testosterone derived from the administered androstenedione as the substrate. The activities of the enzymes defined above were expressed in the ratios (in \%) of the products derived by the enzymes to the administered substrates in the tables of this report.

\section{Results and Discussion}

Effect of phospholipases upon the microsomal enzyme activities of testes.

\section{Phospholipase A}

The microsomal fraction of rat testes was adjusted at $\mathrm{pH} 8.6$ with $0.5 \mathrm{M}$ Tris- $\mathrm{HCl}(\mathrm{pH}$ 9.0) and then the phospholipase A was added (final concentration, $0.1 \% \mathrm{w} / \mathrm{v}$ ). Then, the mixture was incubated at $4^{\circ}$ for $16 \mathrm{hrs}$. (Imai and Sato, 1960; Isselbacher et al., 1962). After the incubation, the mixture was then adjusted at $\mathrm{pH} 7.4$ and an aliquot was reserved for examination of the influence of this lipase upon the microsomal enzyme activities, while the other aliquot was centrifuged at $105,000 \times \mathrm{g}$ for 60 mins., and the precipitates and the supernatant fluid were respectively assayed of the enzyme activities involved in each fraction.

When the untreated microsomal fraction of rat testes was recentrifuged at 105,000 $\times \mathrm{g}$, about one third of total $\Delta^{5}-3 \beta$-hydroxysteroid dehydrogenase activity was found in the supernatant fluid. After treatment with the venomous lipase preparation, total enzyme activity of the lipase-treated mixture was reduced to about $75 \%$ of the sum of the activities found in both the supernatant fluid and the precipitates of the untreated preparation. When the phospholipase-treated microsomal fraction was centrifuged at $105,000 \times \mathrm{g}$, the activities in the supernatant fluid and the precipitates were respectively comparable with the corresponding activities of the untreated microsomal fractions.

When $17 \beta$-hydroxysteroid dehydrogenase activity was examined of the above mentioned two fractions, the similar tendency to the case 
of $\Delta^{5}-3 \beta$-hydroxysteroid dehydrogenase was observed (Table 1).

\section{Phospholipases $C$ and $D$.}

The phospholipases $\mathrm{C}_{1}$ and $\mathrm{D}$ were respectively incubated at $\mathrm{pH} 7.0$ with the testicular microsomes, and then the testicular enzyme activities were examined of the supernatant fluid and the precipitates of the treated and untreated microsomal preparations, res-

Table 1. Effect of phospholipase A upon the microsomal enzyme activities of rat testes

\begin{tabular}{|c|c|c|c|c|}
\hline \multirow{3}{*}{$\begin{array}{l}\text { Preparation } \\
\text { Untreated } \\
\text { microsomal } \\
\text { fraction }\end{array}$} & \multicolumn{2}{|c|}{$\begin{array}{c}\Delta^{5}-3 \beta- \\
\text { hy droxy steroid } \\
\text { dehy drogenase* }\end{array}$} & \multicolumn{2}{|c|}{$\begin{array}{c}17 \beta \text {-hydroxysteroid } \\
\text { dehy drogenose* }\end{array}$} \\
\hline & Sup** & $\mathrm{Ppt}^{* *}$ & Sup** & Ppt** \\
\hline & 21.5 & 60.0 & 7.5 & 51.0 \\
\hline $\begin{array}{l}\text { Phospholi- } \\
\text { pase A } \\
\text { treated } \\
\text { fraction }\end{array}$ & 27.5 & 56.9 & 5.3 & 74.8 \\
\hline
\end{tabular}

* Enzyme activity was expressed as the ratio of products in \% to the administered substrate ( $5 \mu \mathrm{g}$ per flask).

**Sup and Ppt denote respectively the supernatant fluid and the precipitates obtained at $105,000 \times \mathrm{g}$. pectively.

As shown in Table 2, all the enzyme activities related to testosterone formation from pregnenolone were reduced remarkably by the phospholipase $\mathrm{C}$ preparation originated in Bacillus cereus, while, the activities in the supernatant fluid were negligibly small. Also, after incubation of the testicular microsomal fraction with phospholipase $\mathrm{D}$, the testicular enzyme activities were not significantly detected in the supernatant fluid at 105,000 $x$ $\mathrm{g}$, being consistent with the case of phospholipase $\mathrm{C}_{1}$.

It is known that phospholipase A removes the fatty acid from the 2-position of phospholipid, which is a component of the cytomembrane, whereas phospholipase $\mathrm{C}$ and $\mathrm{D}$ release choline and diglyceride respectively from the phospholipid. (Ansell and Hawthorne, 1964). The microsomal enzyme activities related to testosterone production were inhibited by phospholipases $\mathrm{C}$ and $\mathrm{D}$, but not significantly by the phospholipase A preparation. The similar tendency as stated above was reported also of adenosine triphosphatase of cerebral microsomal fraction, which was partly solubilized by some surface active reagents (Swanson et al., 1964).

Table 2. Influence of phospholipases $C_{1}$ and $D$ upon the microsomal enzyme activities of rat testes

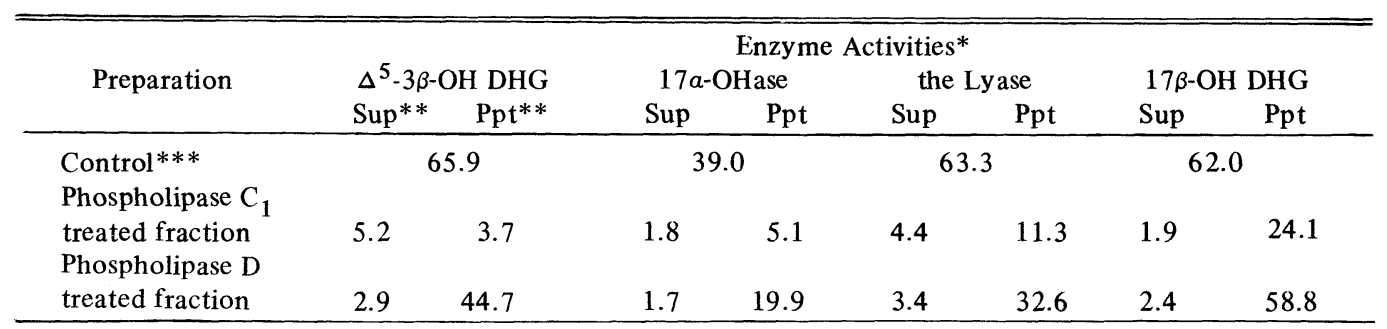

* Enzyme activities were expressed as the ratios of the products in $\%$ to the administered substrate (10 $\mu \mathrm{g}$ per flask).

$\Delta 5-3 \beta-\mathrm{OH}$ DHG, $17 \alpha-\mathrm{OHase}$, the lyase and $17 \beta-\mathrm{OH}$ DHG were respectively the abbreviation of the $\Delta^{5}-3 \beta$-hydroxysteroid dehydrogenase, $17 \alpha$-hydroxylase, the $C_{17}-C_{20}$ lyase and $17 \beta$-hydroxysteroid dehydrogenase.

** same as the note of Table 1 .

*** Total activity of the untreated microsomal fraction. 
From the results obtained from the experiments with the phospholipases, it is suggested that, as an essential part, the enzyme activities related to testosterone synthesis from pregnenolone required the microsomal phospholipoidal component which was susceptible to phospholipases C and D.

Although there was no qualitative difference between the influences of phospholipases $\mathrm{C}$ and $\mathrm{D}, \Delta^{5}-3 \beta$ - and $17 \beta$-hydroxysteroid dehydrogenase activities of testicular microsomes were not so much inhibited by the phospholipase $\mathrm{D}$ as the lyase and 17a-hydroxylase activities, both of which required molecular oxygen and NADPH (Inano et al., 1967; Nakano et al., 1967). Probably, the dehydrogenases group and the group of oxygenrequiring enzymes would occupy different positions in the microsomal particles, particularly in the connection to microsomal phospholipid layer.

Effect of sonication upon the microsomal enzyme activities

\section{10 kilocycle/sec. sonication}

The microsomal fraction of rat testis was suspended in the Tris- $\mathrm{HCl}$ buffered solution ( $\mathrm{pH} 7.4)$, and was sonicated with a 10 kilocycle/sec. (hereafter, abbreviated as KC) sonicator (Tominaga Co. Ltd., Tokyo) for 0.30 , and 60 mins. Then, the resultant preparations were respectively centrifuged at $105,000 \times \mathrm{g}$ for 60 mins., and the supernatant fluid and the precipitates of each preparation

were simultaneously incubated with progesterone- $4-{ }^{14} \mathrm{C}$ and $17 \alpha$-hydroxyprogesterone$7 \alpha-{ }^{3} \mathrm{H}$. When the $17 \alpha$-hydroxylase and the $\mathrm{C}_{17}-\mathrm{C}_{20}$ lyase activities as previously defined were examined, very limited activities of the enzymes were found in the supernatant fluid. The specific activities of the enzymes in the particles $(105,000 \times \mathrm{g}$ precipitate $)$ were relatively higher than the untreated microsomal fraction, as shown in Figure 1, probably because the protein which was devoid of the enzyme activities was solubilized from the microsomes

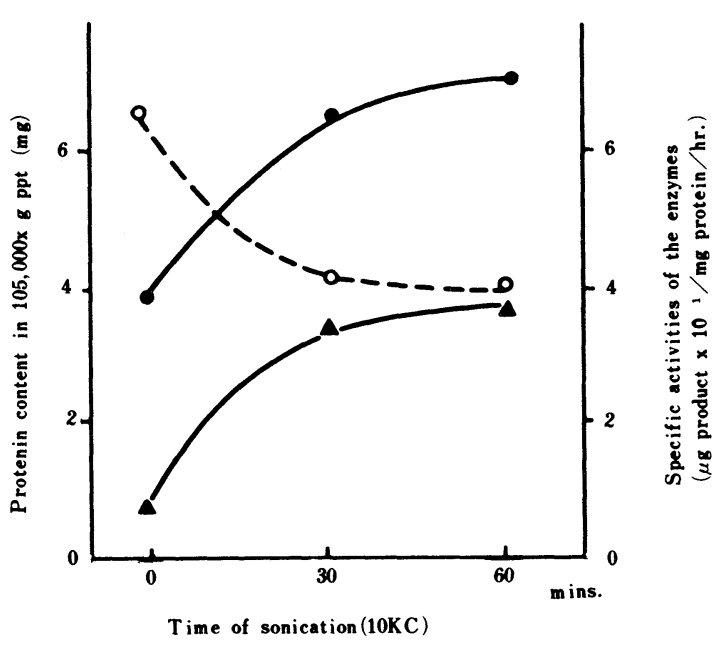

Fig. 1. Influence of $10 \mathrm{KC}$ sonication upon the specific activities of the enzymes and protein content in the $105,000 \times \mathrm{g}$ precipitates.

$\circ$ protein content in the $105,000 \times \mathrm{g}$ precipitates

- specific activity of $17 \alpha$-hydroxylase

$\Delta$ specific activity of the $\mathrm{C}_{17}-\mathrm{C}_{20}$ lyase

by this sonication, whereas the enzyme activities themselves were not influenced by the sonication (Fig. 1).

\section{20 KC sonication}

Testicular microsomal fraction was treated with a $20 \mathrm{KC}$ sonicator (Umeda Electric Co. Ltd., Tokyo) for 5 mins. with cooling. Being consistent with the previously obtained results with the $10 \mathrm{KC}$ sonication, the specific activities of the enzymes in the $105,000 \times \mathrm{g}$ precipitates after the $20 \mathrm{KC}$ sonication become higher than the corresponding activities of the untreated microsomal fraction. Moreover, as indicated in Table 3, appreciable activities of the enzymes were found in the supernatant fluid obtained at $105,000 \times \mathrm{g}$ after $20 \mathrm{KC}$ sonication, and the specific activi- 
Table 3. Influence of sonication of $20 \mathrm{KC}$ upon testicular microsomal enzyme activities

\begin{tabular}{|c|c|c|c|c|c|c|c|c|}
\hline \multirow{3}{*}{ Preparation } & \multicolumn{8}{|c|}{ Enzyme activities* } \\
\hline & \multicolumn{2}{|c|}{$3 \beta-\mathrm{OH}$ DHG } & \multicolumn{2}{|c|}{$17 a-O H a s e$} & \multicolumn{2}{|c|}{ the Lyase } & \multicolumn{2}{|c|}{$17 \beta-\mathrm{OH}$ DHG } \\
\hline & Sup** & $\mathrm{Ppt}^{* *}$ & Sup & Ppt & Sup & Fpt & Sup & Ppt \\
\hline $\begin{array}{l}\text { Control } \\
\text { Sonicated }\end{array}$ & 4.4 & 61.9 & 3.4 & 65.8 & 4.9 & 56.9 & 5.7 & 76.3 \\
\hline preparation & 53.8 & 48.6 & 20.1 & 33.1 & 22.1 & 21.1 & 57.5 & 46.5 \\
\hline $\begin{array}{l}\text { Sep. at } 165,000 \\
\times \mathrm{g}^{* * *}\end{array}$ & $18.4 * * *$ & $26.3 * * *$ & $4.3 * * *$ & $9.8^{* * *}$ & $7.5^{* * *}$ & $13.2 * * *$ & $13.1 * * *$ & $41.7 * * *$ \\
\hline Recombination ${ }^{* * * *}$ & \multicolumn{2}{|c|}{36.8} & \multicolumn{2}{|c|}{12.1} & \multicolumn{2}{|c|}{14.0} & \multicolumn{2}{|c|}{52.2} \\
\hline
\end{tabular}

* Same as the note of Table 2, but the amount of the substrates per flask was $2 \mu \mathrm{g}$.

** Sup and Ppt respectively denotes the supernatant fluid and the precipitate at 105,000 $\times \mathrm{g}$, except the figures marked with $* * *$.

*** The supernatant fluid obtained at $105,000 \times \mathrm{g}$ was centrifuged at $165,000 \times \mathrm{g}$, and the enzyme activities in the supernatant fluid and the precipitates were assayed.

$* * * *$ The activities of the fraction recombined of the supernatant fluid and the precipitate obtained at $165,000 \times \mathrm{g}$ as stated above.

ties of the enzymes were relatively lower than the specific activities of the precipitate obtained simultaneously. This was presumably caused, due to the dilution of the enzyme activities with the solubilized microsomal protein which had no enzyme activity related to the production of testosterone.

In order to examine the status of the enzyme activities in the supernatant fluid obtained at $105,000 \times \mathrm{g}$ furthermore, it was centrifuged at $165,000 \times \mathrm{g}$ for $5 \mathrm{hrs}$., and then the distribution of the enzyme activities were examined of both the supernatant fluid and the precipitates thus obtained.

After the centrifugation, total enzyme activities of the recombined mixture was found to be remarkably reduced in comparison with the activities of the supernatant fluid at $105,000 \times \mathrm{g}$. The remaining activities were found in the both fractions, and under the condition of centrifugation at 165,000 $x$ $\mathrm{g}$, more activities found in the precipitates than in the supernatant fluid. The recombination of the precipitates with the supernatant fluid obtained at $165,000 \times \mathrm{g}$ showed no significant increase to the sum of the individual activities of the two fractions.

By 10 and $20 \mathrm{KC}$ sonications, some part of protein which was constituent of the microsomal particles and was devoid of the steroidogenic activity was solubilized from the microsomal particles, judging from the increased protein concentration but no enzyme activity in the supernatant fluid, and also from the increased specific activities of the enzymes in the precipitates after the sonications.

The active principles remained in the precipitates at $105,000 \times \mathrm{g}$ after $10 \mathrm{KC}$ sonication, and it is suggested that the particles which contained the enzyme activities, still after the sonication, had the similar physical feature to the intact microsomal fraction during the sedimentation, even though the inert protein was solubilized from the particles by this treatment.

On the other hand, by $20 \mathrm{KC}$ sonication, physical characteristics of a part of the microsomal fraction were changed, or, in other words, a part of the enzymically active particles which had been sonicated was no more precipitable at $105,000 \times \mathrm{g}$. Furthermore, by centrifugation at $165,000 \times \mathrm{g}$, however, major part of the $\Delta^{5}-3 \beta$-hydroxysteroid dehydrogenase and the other three enzymic activities were found in the precipitates.

At this stage, total enzyme activities of 
the recombined fraction of the resultant supernatant fluid and precipitates which were obtained at centrifugation at $165,000 \times \mathrm{g}$ were remarkably diminished, in comparison with the corresponding activity before the centrifugation. This suggests that, during this treatment, the enzyme activities which had been solubilized were inactivated, or at least, the essential component(s) of the enzyme systems were inhibited irreversibly.

The $\Delta^{5}-3 \beta$-hydroxysteroid dehydrogenase and the isomerase which were found in the microsomal fraction of bovine corpus luteum (Cheatum and Warren, 1966) and adrenal gland (Cheatum et al., 1967) were detected in the supernatant fluid at $105,000 \times \mathrm{g}$ after sonication, but still, could not be considered as being completely solubilized, because the enzyme activities were precipitated by further centrifugation at $186,000 \times \mathrm{g}$.

Therefore, from the results obtained with sonication, it could be concluded that testicular microsomal fraction consists of the following three parts, namely; 1 . protein which could be solubilized by $10 \mathrm{KC}$ sonication and had no activity of steroidogenesis, 2. the other part of protein which was not solubilized at $10 \mathrm{KC}$ but solubilized at $20 \mathrm{KC}$. This fraction did not contain any appreciable enzyme activities, or if any, easily inactivated. 3. the particles which remained in the insoluble state after 10 and $20 \mathrm{KC}$ sonication, and contained all the enzyme activities, more or less reduced by sonication and the following centrifugation.

\section{Influence of the phospholipases upon the sonicated microsomal enzymes of testis}

As inactive protein was solubilized, and physical properties of the microsomal particles were changed by $20 \mathrm{KC}$ sonication, the microsomal fraction which had been treated by sonication was subjected again to phospholipases $\mathrm{A}$ and $\mathrm{C}$, in order to examine whether or not the sonicated microsomal fraction showed different attitudes to these phospholipases, in comparison with case of intact microsomal fraction.

\section{Influence of phospholipase $A$ upon the microsomal enzymes sonicated with $20 \mathrm{KC}$}

The microsomal suspension in Tris- $\mathrm{HCl}$ buffered solution was sonicated with $20 \mathrm{KC}$ for 2 min., and then the phospholipase A solution was added to the sonicate which was adjusted at $\mathrm{pH} 8.6$ by $0.5 \mathrm{M}$ Tris-HCl buffer ( $\mathrm{pH}$ 9.0). Then the mixture was incubated at $4^{\circ}$ for $16 \mathrm{hrs}$. After the incubation, the mixture was adjusted at $\mathrm{pH} 7.4$ by $0.1 \mathrm{~N} \mathrm{HCl}$, then centrifuged at $105,000 \times \mathrm{g}$ for 60 mins.

As shown in Table 4, the supernatant fluid at $105,000 \times \mathrm{g}$ of the sonicated and then phospholipase A-treated preparation had somewhat increased activities of these two hydroxysteroid dehydrogenases in comparison with these of the supernatant fluid of the untreated microsomal fraction, while the $17 \alpha$-hydroxylase and the lyase activities in the supernatant fluid were not significantly increased by

Table 4. Influence of phospholipase A upon the sonicated microsomal preparation of rat testes

\begin{tabular}{|c|c|c|c|c|c|c|c|c|}
\hline \multirow{3}{*}{ Preparation } & \multicolumn{8}{|c|}{ Enzyme activities* } \\
\hline & \multicolumn{2}{|c|}{$3 \beta-\mathrm{OH} \mathrm{DHG}$} & \multicolumn{2}{|c|}{$17 a-O H a s e$} & \multicolumn{2}{|c|}{ the Lyase } & \multicolumn{2}{|c|}{$17 \beta-\mathrm{OH}$ DHG } \\
\hline & Sup $* *$ & Ppt & Sup & Ppt & Sup & Ppt & Sup & Ppt \\
\hline Control & 3.1 & 71.5 & 2.9 & 78.5 & 5.6 & 48.3 & 3.0 & 64.9 \\
\hline $\begin{array}{l}\text { Sonicated and } \\
\text { Phospholipase A- } \\
\text { treated fraction }\end{array}$ & 30.1 & 48.1 & 7.7 & 31.3 & 6.4 & 15.7 & 11.3 & 42.0 \\
\hline
\end{tabular}

* The amount of the substrates per tlask was $5 \mu \mathrm{g}$., and expressed same as mentioned in the note of Table 2.

** The supernatant fluid (Sup) and the precipitates (Ppt) at 105,000 $\times \mathrm{g}$. 
these combined treatments. Furthermore, recombination of the supernatant fluid and the precipitates proved no significant increase due to the interaction between the two fractions.

These results were found principally consistent with the results obtained by incubation of the sonicated preparation with the phospholipase $\mathrm{A}$ at $37^{\circ}$ for 10 mins.

The supernatant fluid at $105,000 \times \mathrm{g}$ in which the $3 \beta$ - and 17 $\beta$-hydroxysteroid dehydrogenase activities were significantly increased by the procedures was further centrifuged at $165,000 \times \mathrm{g}$ for $5 \mathrm{hrs}$. By the centrifugation, major part of the two dehydrogenase activities were found in the precipitates. Specific activities of the enzymes were found higher in the $165,000 \times \mathrm{g}$ precipitates than the supernatant fluid (Table 5).

\section{Influence of phospholipase $C$ upon the} sonicated microsomal enzyme activities

Testicular microsomal suspension was sonicated in the same manner as above described, and an aliquot of the sonicate was centrifuged at $105,000 \times \mathrm{g}$ for 60 mins., while the other aliquot was incubated with phospholipase $\mathrm{C}_{2}$ preparation at $37^{\circ}$ for 30 mins. After incubation with the lipase, the incubation mixture was centrifuged at $105,000 \times \mathrm{g}$ for 60 mins. Then, the sonicated preparation without treatment with phospholipase $\mathrm{C}_{2}$, and
Table 5. Further studies on the effect of sonication and phospholipase A treatment upon testicular hydroxysteroid dehydrogenases

\begin{tabular}{|c|c|c|c|c|}
\hline & \multicolumn{4}{|c|}{ Enzyme activities } \\
\hline & \multicolumn{2}{|c|}{$3 \beta-\mathrm{OH}$ DHG } & \multicolumn{2}{|c|}{$17 \beta-\mathrm{OH}$ DHG } \\
\hline & Sup** & $\mathrm{Ppt}^{* *}$ & Sup & Ppt \\
\hline Control & 5.5 & 62.7 & 4.3 & 38.9 \\
\hline $\begin{array}{l}\text { Sonicated and } \\
\text { phospholipase- } \\
\text { A treated } \\
\text { fraction }\end{array}$ & 72.0 & 75.0 & 12.1 & 40.8 \\
\hline Sep. at $* * *$ & & & & \\
\hline $165,000 \times \mathrm{g}$ & $\begin{array}{l}7.8 * * * \\
(2.7)\end{array}$ & $\begin{array}{l}29.9^{*} \\
(8.7)\end{array}$ & $\begin{array}{c}* * 3.8 * * * \\
(0.7)\end{array}$ & $\begin{array}{l}36.2 * * * \\
(4.5)\end{array}$ \\
\hline
\end{tabular}

* Expressed as the note of Table 2. (Substrate per flask, $5 \mu \mathrm{g}$ ).

** at $105,000 \times \mathrm{g}$ except the figures marked with $* * *$.

$* * *$ The supernatant fluid at $105,000 \times \mathrm{g}$ was centrifuged at $165,000 \times \mathrm{g}$ for $5 \mathrm{hrs}$.

The figures in parenthesis indicate the specific activities of the enzymes $\left(\mu \mathrm{g}\right.$ of product/mg protein $\left.\times 10^{2}\right)$.

the sonicated and then phospolipase C-treated preparations were respectively examined of the enzyme activities related to androstenedione synthesis from pregnenolone, after centrifugation at $105,000 \times \mathrm{g}$.

As shown in Table 6, the enzyme activities in the supernatant fluid of the sonicate were significantly enhanced in comparison with the corresponding activities of the unsonicated microsomal preparation, being con-

Table 6. The combined effects of sonication and phospholipase $C_{2}$ upon testicular microsomal enzyme activities

\begin{tabular}{|c|c|c|c|c|c|c|}
\hline \multirow{3}{*}{ Preparation } & \multicolumn{6}{|c|}{ Enzyme activities* } \\
\hline & \multicolumn{2}{|c|}{$3 \beta-\mathrm{OH}$ DHG } & \multicolumn{2}{|c|}{$17 a-$ OHase } & \multicolumn{2}{|c|}{ the Lyase } \\
\hline & Sup** & $\mathrm{Ppt}^{* *}$ & Sup & Ppt & Sup & Ppt \\
\hline Control & 3.3 & 79.2 & 2.7 & 75.0 & 4.5 & 86.5 \\
\hline Sonicated $20 \mathrm{KC}$ fraction & $\begin{array}{l}52.9 \\
(14.7) * * *\end{array}$ & $\begin{array}{c}74.8 \\
(26.7)\end{array}$ & $\begin{array}{l}27.5 \\
(7.6)\end{array}$ & $\begin{array}{c}74.4 \\
(26.6)\end{array}$ & $\begin{array}{l}23.7 \\
(6.6)\end{array}$ & $\begin{array}{c}73.6 \\
(26.3)\end{array}$ \\
\hline $\begin{array}{l}\text { Sonicated and then } \\
\text { Phospholipase } \mathrm{C}_{2} \text {-treated fraction }\end{array}$ & $\begin{array}{c}4.4 \\
(8.8)\end{array}$ & $\begin{array}{c}6.0 \\
(1.8)\end{array}$ & $\begin{array}{c}1.6 \\
(3.2)\end{array}$ & $\begin{array}{c}5.2 \\
(1.5)\end{array}$ & $\begin{array}{c}4.8 \\
(9.6)\end{array}$ & $\begin{array}{c}8.4 \\
(2.5)\end{array}$ \\
\hline
\end{tabular}


sistent with the result previously described.

By incubation of the sonicated fraction treated with the phospholipase $\mathrm{C}_{2}$, however, the remarkable reduction of the enzyme activities was observed both in the precipitates and the supernatant fluid. The specific activities of the precipitate of the sonicate without lipase treatment were remarkably higher than the corresponding activities of the precipitates obtained from the sonicated and then the lipase-treated fraction.

The enzyme activities of the sonicated microsomes related to androstenedione formation from pregnenolone were also strongly destroyed by phospholipase $\mathrm{C}_{2}$, but not so much by phospholipase $\mathrm{A}$, and this result is consistent with the result obtained by the phospholipases upon the intact microsomal fractions.

Therefore, the inactive protein which was solubilized by the sonication and the enzyme protein seem to locate independently each other in the microsomal particle. In other words, phospholipase $\mathrm{C}$ and probably $\mathrm{D}$ worked directly and more or less selectively upon the microsomal phospholipid closely connected to enzyme protein, without any interaction of the protein which was devoid of the enzyme activity and solubilized by the sonication.

There was no significant increase by recombination of the precipitates and the supernatant fluid at $105,000 \times \mathrm{g}$, suggesting that these two fractions separated by the centrifugation were not mutually complementary.

\section{Effects of other treatments upon the} microsomal enzyme activities of testis

\section{Organic solvents}

\section{Acetone}

The microsomal suspension obtained from rat testes was cooled on ice and then cold acetone $\left(-10^{\circ}\right)$ was added drop by drop into the microsomal suspension with constant stirring. The resultant precipitates were centrifuged off at $400 \times \mathrm{g}$, and the acetone in the supernatant fluid was evaporated off under the reduced pressure. When the acetone dried powder, acetone soluble fraction, and the recombined mixture of the above two fractions were assayed of the enzyme activities related to testicular steroidogenesis, all these three preparations were found as devoid of the enzyme activities examined.

\section{2. n-Butanol}

$n$-Butanol was added into the testicular microsornal suspension, according to the similar procedure stated in the above case. Then, the mixture was stirred at $0^{\circ}$ for 30 mins., and then centrifuged at $400 \times \mathrm{g}$. Then, the water layer was dialyzed against $0.01 M$ Tris-

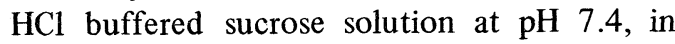
order to remove the organic solvent, but the portion in the cellophane bag had no enzyme activities related to the androgen biosynthesis.

\section{Detergents}

When the sodium lauryl sulfate, as an ionic detergent $(0.03 \%)$, Triton X-100 (2\%) and sodium deoxycholate $(1 \%$ in glycylglycine solution) as non-ionic detergents were added to the testicular microsomal fraction, turbidity of the preparation was remarkably reduced, but the enzyme activities related to the androgen production were destroyed by these detergents.

\section{Freezing and thawing}

The testicular microsomal fraction which was suspended in the deionized water was frozen in the liquid nitrogen and then thawed in water bath. This procedure was repeated upto 15 times, and after this treatment, no enzyme activity was observed in the supernatant fluid at $105,000 \times \mathrm{g}$.

Attempts to remove the lipoidal part from the microsomal fraction with organic solvents such as acetone and $n$-butanol, and then to solubilize the enzyme activities related to testosterone formation were not successful. Being consistent with the previous findings by 
the usage of phospholipases $\mathrm{C}$ and $\mathrm{D}$, this result suggests that intact phospholipid which was connected to the enzyme protein seems to be essential for display of the enzyme activities.

Furthermore, it was proved by turbidimetry that, the detergents were found to be able to solubilize the microsomal fraction, but, by these chemical detergents, the enzyme activities were completely inactivated. Microsomal enzyme system related to hydroxylation of 3,4-benzpyrene in the liver became not precipitable by treatment of a non-ionic detergent or Triton $\mathrm{N}-101$, but was precipitated by further centrifugation at the same gravitational field for prolonged time (Silverman and Talalay, 1967).

By repeated procedure of freezing and thawing, some part of microsomal protein which was devoid of the enzyme activity was solubilized, but the enzyme activities remained in the form of particle.

Individual enzymic characteristics of testicular microsomes had been studied in the state of particles (Lynn and Brown, 1958; Inano et al., 1967, Nakano et al., 1967), and as the testicular enzymes such as $17 \alpha$-hydroxylase, the lyase and 17ß-hydroxysteroiddehydrogenase were inhibited by $p$-chloromercuribenzoate, these microsomal enzymes retained SH-group in the molecules which were related closely to the enzyme activities.

\section{Acknowledgements}

The authors are grateful to Dr. S. Akaboshi, and $\mathrm{Mr}$. H. Inano, in this Institute for their interests and discussion in the course of this experimentation. Also the authors are indebted to Dr. M. Namekata, Laboratory of Racing Chemistry, Dr. Y. Nakazawa, Tokyo Medico-Dental University, and Dr. M. Matsumoto, Shizuoka College of Pharmacy for their kind offer of the phospholipase preparations $\mathrm{A}, \mathrm{C}_{1}, \mathrm{C}_{2}$ and $\mathrm{D}$ for this experimentation. This work is partly supported by Research Grant (CA-07038) from National Institutes of Health, Bethesda, Md., U.S.A. and also by a grant from Ministry of Education of Japan.

\section{References}

Ansell, G. B. and J. N. Hawthorne. Phospholipids, B.B.A. Library, Volume 3, p. 152 (1964).

Cheatum, S. G., A. W. Douville and J. C. Warren (1967). Biochim. Biophys. Acta 137, 172.

Cheatum, S. G. and J. C. Warren (1956). Ibid. $122,1$.

Habermann, E. and W. Neumann (1954). Z. Physiol. Chem. 297, 170.

Imai, Y. and R. Sato (1960). Biochim. Biophys. Acta 42, 164.

Inano, H. and B. Tamaoki (1968). Endocrinol. Japon. 15, 197.

Inano, H., H. Nakano, M. Shikita and B. Tamaoki (1967). Biochim. Biophys. Acta 137, 540.

Isselbacher, K. J., M. F. Chrabas and R. C. Quinn (1962). J. Biol. Chem. 237, 3033.

Lynn, W. S. Jr. and R. H. Brown (1958). Ibid. 232, 1015.

Macfarlane, M. G. and B.C.J.G.Knight (1941). Biochem. J. 35, 884.

Matsumoto, M., Y. Suzuki and K. Tamiya (1967). Japanese J. Exp. Med. 37, 355.

Molnar, D.M. (1962). J. Bacteriol. 84, 147.

Nakano, H., H. Inano, H. Sato, M. Shikita and B. Tamaoki (1967). Biochim. Biophys. Acta 137, 335.

Omura, T., R. Sato, D. Y. Cooper, O. Rosenthal and R. W. Estabrook (1965). Fed. Proc. 24, 1181.

Reid, E. Enzyme Cytology, ed. by D. B. Roodyn, Academic Press, London, p.321 (1967).

Shikita, M. and B. Tamaoki (1965). Endocrinology 76, 563.

Shikita, M., H. Inano, and B. Tamaoki (1967). Biochemistry (Wash) 6, 1760.

Silverman, D. A. and P. Talalay (1967). Mol. Pharmacol. 3, 90.

Swanson, P. D., H. F. Bradford, and H. McIlwain (1964). Biochem. J. 92, 235. 